\title{
LEMBAR KERJA PESERTA DIDIK (LKPD) BERBASIS PROBLEM SOLVING POLYA
}

\author{
Lilis Nurliawaty', Mujasam², Irfan Yusuf ${ }^{3}$, Sri Wahyu Widyaningsih ${ }^{4}$ \\ 1,2,3,4 Jurusan Pendidikan Fisika, Universitas Papua, Indonesia \\ E-mail: lilisnurliawaty16@gmail.com¹,
}

\begin{abstract}
Abstrak
Kurangnya penggunaan bahan ajar yang tepat serta tidak sesuai dengan kebutuhan peserta didik menyebabkan kurangnya kemampuan menganalisis peserta didik terhadap proses pemecahan masalah. Penelitian pengembangan Lembar Kerja Peserta Didik (LKPD) berbasis problem solving Polya pada materi kalor bertujuan untuk mengembangkan LKPD yang valid, praktis, dan efektif. Tahapan pengembangan menggunakan model 4D yang dimodifikasi menjadi 3D, yaitu Define (pendefinisian), Design (perencanaan), dan Development (pengembangan). Hasil validitas perangkat pembelajaran berada pada kategori valid, diperoleh dari hasil perhitungan CVI berada pada rentang 0-1 dan dikatakan dalam kategori reliabel dengan nilai $r_{11}$ yang lebih besar dari $r_{\text {tabel }}\left(r_{\text {hitung }}>r_{\text {tabel }}\right)$. Hasil analisis angket respons peserta didik diperoleh rerata persentase hasil analisis sebesar $87,9 \%$. Hasil analisis lembar penilaian pembelajaran Fisika menggunakan LKPD berbasis problem solving Polya diperoleh rerata persentase hasil analisis pada pertemuan pertama sebesar $77,33 \%$ dengan kategori baik, rerata persentase hasil analisis pada pertemuan kedua sebesar $81,11 \%$ dengan kategori sangat baik dan rerata persentase hasil analisis pada pertemuan ketiga adalah $78,89 \%$ dengan kategori baik. Sehingga dapat dikatakan bahwa LKPD berbasis problem solving Polya yang dikembangkan valid, praktis, dan efektif untuk digunakan.
\end{abstract}

Kata kunci: Pengembangan, LKPD, problem solving Polya.

\section{Abstract}

Lack of exact use of teaching materials and does not correspond to the needs of student leads to lack of analytical ability of students to the process of problem solving. Research development worksheets based on Polya problem solving on the heat material aims to develop valid LKPD, practical, and effective. Stages of development using the 4D model was modified into 3D, namely define (definition), Design (planning), and Development (development) The results of the validity of the learning device in the category valid, obtained from the calculation of $\mathrm{CVI}$ are in the range $0-1$ and said in category reliably with $r_{11}$ value greater than $r_{\text {tabel }}\left(r_{\text {count }}>r_{\text {tabel }}\right)$. The results of the analysis of questionnaire responses of students obtained an average percentage of $87.9 \%$ on the analysis. The analysis result of sheets assessment of learning physics used LKPD-based Polya problem solving obtained average percentage analysis results in the first meeting is $77.33 \%$ with good category, the average percentage of the results of the analysis at the second meeting is $81.11 \%$ with a very good category and average of results percentage analysis at the third meeting is $78.89 \%$ with good category. So it can say that LKPDbased Polya problem solving developed valid, practical and effective to use.

Keywords: Development, LKPD, problem solving Polya. 


\section{PENDAHULUAN}

Fisika adalah ilmu yang membahas tentang alam dan gejalanya, dari yang bersifat nyata hingga yang bersifat abstrak. Widyaningsih (2011) mengatakan bahwa fisika adalah bagian dari ilmu pengetahuan alam yang merupakan hasil kegiatan manusia berupa pengetahuan, gagasan dan konsep yang terorganisir tentang alam sekitar yang diperoleh dari pengalaman melalui serangkaian proses ilmiah. Sebagai ilmu yang mempelajari fenomena alam, fisika juga memberikan pelajaran yang baik kepada manusia untuk hidup selaras berdasarkan hukum alam. Fisika sebagai mata pelajaran diharapkan dapat menumbuhkan kemampuan berpikir untuk memecahkan permasalahan dalam kehidupan sehari-hari sehingga perlu diajarkan secara optimal. Namun pada kenyataannya, proses pembelajaran IPA termasuk di dalamnya Fisika di sekolah masih terdapat banyak kekurangan.

Pembelajaran Fisika bertujuan untuk membekali peserta didik memiliki sederet kompetensi teori dan konsep fisika yang telah dijabarkan dalam standar kompetensi dan kompetensi dasar yang tersirat dalam Permendiknas Nomor 22 tahun 2007 tentang Standar Isi dan nomor 23 tahun 2007 tentang Standar Kompetensi Lulusan Khusus untuk pelajaran Fisika.

Permendiknas Nomor 22 tahun 2007 tentang Standar Isi menyatakan bahwa fungsi dan tujuan mata pelajaran Fisika di SMP adalah agar peserta didik memiliki kemampuan, yaitu: 1) memupuk sikap ilmiah yang mencakup: jujur, terbuka dalam menerima pendapat berdasarkan bukti-bukti tertentu, kritis terhadap pernyataan ilmiah yaitu tidak mudah percaya tanpa ada dukungan hasil observasi empiris, dapat bekerjasama dengan orang lain dan 2) memberi pengalaman untuk dapat mengajukan dan menguji hipotesis melalui percobaan merancang dan merakit instrumen percobaan, mengumpulkan, mengolah, dan menafsirkan data, menyusun laporan, serta mengkomunikasikan hasil percobaan secara lisan dan tertulis.

Dari pernyataan di atas dapat diuraikan bahwa pelajaran fisika di SMP dimaksudkan sebagai sarana untuk melatih para peserta didik agar dapat menguasai pengetahuan, konsep, dan prinsip fisika, memiliki kecakapan ilmiah, memiliki keterampilan proses sains, dan keterampilan berpikir kritis. Dari sebagian banyak kompetensi yang menjadi tuntutan Permendiknas bahwa salah satu poin dari standar isi dalam mencapai fungsi dan tujuan tersebut, keterampilan berpikir kritis merupakan kompetensi yang sangat penting untuk dilatihkan.

Analisis adalah kemampuan untuk memecahkan atau menguraikan suatu materi atau informasi menjadi komponen-komponen yang lebih kecil sehingga lebih mudah dipahami. Level ini lebih rumit karena peserta didik sadar akan proses berpikir yang mereka gunakan. Menurut Sudjana (2008) analisis adalah usaha untuk memilih integritas menjadi unsur-unsur atau bagian-bagian sehingga jelas hirarki atau susunannya. Sementara menurut pendapat Bloom yang telah direvisi oleh Anderson dan Krathwohl (2010) menganalisis melibatkan proses memecah-mecah materi menjadi bagian-bagian kecil dan menentukan bagaimana hubungan antar bagian dan struktur keseluruhannya. Analisis merupakan kecakapan yang kompleks yang memanfaatkan kecakapan dari ketiga tipe kognitif sebelumnya. Dengan analisis diharapkan peserta didik mampu memiliki pemahaman yang kompreherensif dan terintegritas.

Hasil wawancara dengan guru IPA di SMP Santo Don Bosco diperoleh informasi terdapat $75 \%$ peserta didik yang belum memenuhi KKM dan hanya terdapat $25 \%$ peserta didik yang memenuhi KKM. Hal ini disebabkan oleh kurangnya penguasaan keterampilan peserta didik dalam menganalisis yang membutuhkan penalaran dan pemecahan masalah (problem solving). Kurangnya kemampuan menganalisis peserta didik salah satunya penggunaan bahan ajar yang kurang tepat. Menurut 
hasil wawancara dengan peserta didik, sebagian besar merasa bahan ajar yang biasa digunakan kurang menarik, inovatif, kurang variatif, dan tidak sesuai dengan tingkat kebutuhan peserta didik. Selain itu juga soal-soal yang diberikan hanya sebatas mengetahui, memahami dan menerapkan, belum pada level menganalisis.

Pelajaran Fisika pada umumnya merupakan pelajaran yang harus dipahami bukan sekadar dihafalkan. Kurangnya kemampuan peserta didik tersebut perlu segera ditemukan solusinya. Penggunaan media pembelajaran seperti buku Lembar Kerja Peserta Didik (LKPD) menjadi salah satu alternatif untuk meningkatkan hasil belajar peserta didik. Penyajian LKPD dapat dikembangkan dengan berbagai macam inovasi. Terdapat berbagai macam inovasi baru yang dapat diterapkan dalam penulisan LKPD salah satu diantaranya memadukan LKPD dengan model problem solving. Model problem solving dirasa cukup tepat untuk meningkatkan kemampuan berpikir analisis, karena metode ini diberikan prosedur pemecahan masalah dengan berbagai pendekatan atau model (Ikhwanudin, 2010).

Ada beberapa jenis model problem solving yaitu yang dikembangkan oleh John Dewey, Karl Abrecht, Berry Beyer, Solso, Wankat dan Oreovocz serta model problem solving yang dikembangkan oleh Polya. Masingmasing ahli tersebut, mengembangkan problem solving dengan langkahlangkah yang berbeda-beda.

Menurut Polya (1947) ada empat langkah dalam model problem solving yaitu (1) memahami masalah (understanding), (2) menentukan rencana strategi pemecahan masalah (planning), (3) menyelesaikan strategi penyelesaian masalah (solving), (4) memeriksa kembali jawaban yang diperoleh (checking).

Model pembelajaran berbasis problem solving Polya dirasa cocok digunakan untuk peserta didik karena menyediakan lebih banyak langkahlangkah dalam memecahkan suatu masalah. Hal ini sesuai dengan pernyataan Kokom Komariyah yang menyatakan model problem solving Polya dimulai dengan pemberian masalah, kemudian siswa berlatih memahami, menyusun strategi dan melaksanakan strategi sampai dengan menarik kesimpulan. Oleh karena itu, model pemecahan masalah (problem soving) menurut Polya dapat digunakan untuk membantu peserta didik dalam meningkatkan kemampuan menganalisis. Hal ini sejalan dengan hasil penelitiannya Widiana dan Jampel (2016) yang menemukan bahwa model pembelajaran pemecahan masalah SSCS (polya) berpengaruh positif terhadap hasil belajar statistik inferensial mahasiswa di Universitas Pendidikan Ganesha.

Kelengkapan bahan ajar untuk mata pelajaran fisika sangat menunjang pembelajaran peserta didik, namun belum tersediannya (LKPD) yang efektif dan efisien bagi peserta didik. Alasan ini mendorong peneliti untuk melakukan Pengembangan Lembar Kerja Peserta Didik (LKPD) berbasis Problem Solving Polya terhadap Kemampuan Menganalisis Peserta Didik pada Materi Kalor di Kelas VII A SMP Santo Don Bosco Manokwari. Tersedianya LKPD yang sesuai dengan karakteristik peserta didik sangat penting. Hal ini sesuai dengan penelitian Widyaningsih, S.W dkk (2015) yang menyatakan bahwa jika disediakan LKPD maka peserta didik akan berusaha berkerja keras dalam mengisi LKPD yang disediakan oleh guru.

Tujuan dari penelitian ini yaitu untuk menghasilkan produk berupa LKPD berbasis problem solving Polya pada materi kalor kelas VII SMP yang valid, praktis, dan efektif.

\section{METODE}

Penelitian ini merupakan penelitian dan pengembangan (research and development atau $\mathrm{R}$ \& D) karena mengembangkan suatu produk dan menguji keefektifan, kevalidan, dan kepraktisan produk. Produk yang dikembangkan menggunakan model 4D dan diuji validitas dan efektifitasnya adalah perangkat pembelajaran LKPD berbasis 
problem solving yang meliputi RPP, bahan ajar berupa LKPD, angket respon peserta didik, dan lembar observasi aktifitas peserta didik. Penentuan kelas uji terbatas dengan menggunakan teknik Purposive Sampling. Teknik sampling purposive adalah teknik penentuan sampel dengan pertimbangan tertentu, yaitu dipilih kelas VII dengan pertimbangan bahwa di kelas tersebut peneliti telah melakukan wawancara dengan guru mata pelajaran dan wali kelas sehingga karakteristik peserta didik dapat diketahui. Jumlah peserta didik di kelas VII A SMP Santo Don Bosco adalah 15 orang dengan 12 peserta didik dan 3 peserta didik lakilaki.

Model pengembangan yang digunakan dalam penelitian mengacu pada model Thiagarajan (4D) yang terdiri dari empat tahap yaitu pendefinisian (define), perancangan (design), pengembangan (develop) dan penyebaran (disseminate). Namun dalam penelitian ini peneliti hanya sampai pada tahap pengembangan (develop). Tahap pendefinisian (define) berupa Analisis SK, KD dan indikator kompetensi, kondisi peserta didik, kondisi sekolah, teori dan filosofi pembelajaran, konteks kurikulum, perkembangan ilmu pengetahuan, teknologi dan sains (IPTEKS), isu-isu saat ini, refleksi peserta didik, dan refleksi guru. Tahap perancangan (define) Dilakukan penyusunan RPP yang bertujuan untuk menyediakan acuan dalam pelaksanaan pembelajaran yang akan dilakukan dalam penerapan LKPD yang telah dikembangkan. Tahap pengembangan (develop) berupa validasi, yang bertujuan untuk menguji tingkat kepraktisan, validitas, dan keefektifan RPP, LKPD, soal-soal untuk mengukur kemampuan analisis peserta didik (C4), angket respon peserta didik, dan lembar penilaian pembelajaran Fisika yang dihasilkan. Revisi yang dilakukan setelah LKPD divalidasi oleh validator sebelum dilakukan pembelajaran kepada peserta didik. Analisis hasil pengembangan yang dimaksudkan untuk mengumpulkan data yang digunakan untuk pertimbangan dalam menetapkan kelayakan LKPD dalam pembelajaran Fisika di SMP kelas VII A.

Penelitian ini meliputi dua tahap yaitu mengembangkan media pembelajaran LKPD dan uji coba perangkat di lapangan menggunakan problem solving Polya. Instrumen pembelajaran yang dilakukan dalam penelitian yaitu: (1) lembar validasi perangkat pembelajaran yang digunakan untuk memvalidasi perangkat pembelajaran yang akan digunakan dalam tahap implementasi yang terdiri dari RPP, LKPD lembar validasi ini diisi oleh ahli, (2) lembar angket respon peserta didik, angket ini bertujuan untuk memperoleh data angket mengenai respons peserta didik berupa masukan dari peserta didik terhadap perangkat pembelajaran yang diajarkan guru, dan (3) lembar penilaian pembelajaran fisika menggunakan LKPD berbasis problem solving Polya dibuat untuk mengetahui hasil pembelajaran peserta didik selama proses pembelajaran menggunakan LKPD berbasis problem solving Polya, lembar ini diisi oleh peneliti.

Untuk menganalisis data pada pengembangan perangkat pembelajaran ini digunakan tes analisi statistik deskriptif. Data yang dianalisis adalah data hasil validasi perangkat pembelajaran RPP, LKPD, angket respon peserta didik, dan lembar penilaian pembelajaran Fisika. Analisis data yang diperoleh dikelompokkan menjadi tiga yaitu (1) analisis data kevalidan perangkat pembelajaran (RPP, LKPD, angket respon peserta didik dan lembar penilaian pembelajaran fisika), (2) analisis data kepraktisan perangkat pembelajaran (RPP, LKPD, angket respon peserta didik dan lembar penilaian pembelajaran Fisika), dan (3) analisis data keefektifan perangkat pembelajaran (RPP, LKPD, angket respon peserta didik dan lembar penilaian pembelajaran fisika).

\section{HASIL DAN PEMBAHASAN}

Hasil penelitian yaitu LKPD berbasis problem solving Polya yang valid, praktis, dan efektif. Pada tahap pengembangan terdapat validasi ahli 
dan uji pengembangan. (1) Validasi dilakukan untuk mengetahui kevalidan perangkat pembelajaran Fisika dengan mempertimbangkan aspek-aspek yang telah ditentukan. Hasil validasi ahli terhadap perangkat pembelajaran yang meliputi RPP, LKPD, angket respons peserta didik dan lembar penilaian pembelajaran Fisika didapat hasil yang valid dengan rentang kevalidan 0-1 disetiap aspek indikatornya dan didapat hasil yang reliabel dimana $r_{\text {hitung }}>r_{\text {tabel }}$. (2) dalam uji pengembangan yang dianalisis datanya adalah instrumen pendidikan berupa angket respons peserta didik dan lembar penilaian pembelajaran Fisika. Angket respons peserta didik dibagikan masing-masing peserta didik setelah kegiatan pembelajaran.

Angket respons peserta didik diberikan setelah pembelajaran dengan menggunakan LKS berbasis problem solving Polya dilaksanakan yang bertujuan untuk mengetahui tanggapan peserta didik selama proses pembelajaran berlangsung (Hidayat, 2014). Angket respons peserta didik ini terdiri dari empat indikator yang dijabarkan menjadi 20 pernyataan. Dari 20 pernyataan tersebut terdapat 10 pernyataan positif dan 10 pernyataan negatif. Rata-rata persentase pilihan jawaban peserta didik pada indikator pertama yaitu minat peserta didik terhadap pembelajaran Fisika sebelum menggunakan LKPD adalah 80,8\%. Kemudian rata-rata persentase pilihan jawaban peserta didik pada indikator kedua yaitu desain LKPD berbasis problem solving Polya adalah 85,9\%, indikator ketiga yaitu isi LKPD berbasis problem solving Polya adalah 91,7\% dan rata-rata persentase pilihan jawaban peserta didik pada indikator keempat pembelajaran Fisika dengan menggunakan LKPD berbasis problem solving Polya adalah 93,3\%. Sedangkan lembar penilaian pembelajaran Fisika diisi oleh peneliti berdasarkan hasil kerja peserta didik melalui tahap-tahap dalam LKPD problem solving Polya yang dibagikan kepada peserta didik. Lembar penilaian ini terdiri dari empat tahapan dalam LKPD yang berisi beberapa aktifitas peserta didik yang akan dinilai. Hasil rata-rata persentase penilaian aktifitas peserta didik berdasarkan tahapan LKPD pada pertemuan pertama adalah $77,33 \%$ dengan katergori baik, rata-rata persentase penilaian aktifitas peerta didik pada pertemuan kedua adalah 81,11 \% dengan kategori sangat baik dan ratarata persentase penilaian aktifitas peserta didik pada pertemuan ketiga adalah 78,89 \% dengan kategori baik.

Berdasarkan hasil persentase ratarata angket respons peserta didik menunjukkan bahwa peserta didik memberikan respons yang positif terhadap kegiatan pembelajaran yang telah dilaksanakan yaitu pembelajaran menggunakan LKPD berbasis problem solving Polya. Hal ini dibuktikan dengan hasil angket respons peserta didik yang menunjukkan minat peserta didik terhadap pembelajaran Fisika sebelum menggunakan LKPD berbasis problem solving Polya sebesar $80,8 \%$. Namun, setelah melakukan pembelajaran menggunakan LKPD berbasis problem solving Polya menunjukkan peningkatan minat peserta didik yaitu $93,3 \%$. Hal ini menunjukkan bahwa peserta didik tertarik terhadap pembelajaran Fisika dengan menggunakan LKPD berbasis problem solving Polya. Dari hasil tersebut secara umum LKPD berbasis problem solving Polya memberikan efek yang positif terhadap pembelajaran di kelas yang dibuktikan dengan meningkatnya kemampuan menganalisis peserta didik yang meningkat dari sebelum diberi perlakuan pembelajaran menggunakan LKPD berbasis problem solving Polya dan setelah diberi LKPD berbasis problem solving Polya.

Pada Gambar 1 menunjukkan minat peserta didik terhadap pembelajaran fisika sebelum menggunakan LKPD berbasis problem solving Polya sebesar $81 \%$. Namun, setelah melakukan pembelajaran menggunakan LKPD berbasis problem solving Polya menunjukkan peningkatan minat peserta didik, yaitu $93 \%$. 


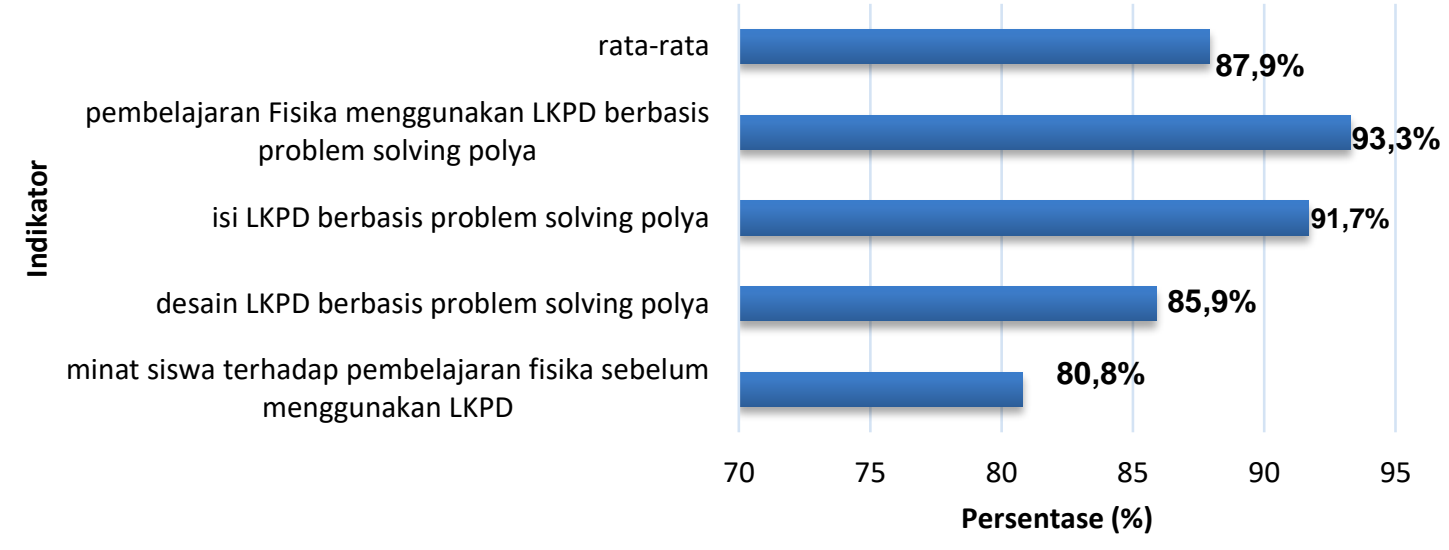

Gambar 1. Persentase hasil angket respon peserta didik

Hasil penilaian dalam pembelajaran Fisika menggunakan LKPD berbasis problem solving Polya juga menunjukkan bahwa LKPD berbasis problem solving Polya mampu meningkatkan kemampuan memecahkan masalah peserta didik. Peningkatan tersebut dapat dilihat dari perolehan indikator lembar observasi aktifitas peserta didik yang berada pada kategoti baik dan sangat baik. Pada pertemuan pertama rata-rata perentase diperoleh 77,33 dengan kategori baik, kemudian pada pertemuan kedua diperoleh rata-rata persentase sebesar $81,11 \%$ sengan kategori sangat baik dan pertemuan ketiga rata-rata persentase diperoleh $78,89 \%$ dengan kategori baik. Hal ini dikarenakan melalui penyelesaian soal-soal yang ada pada LKPD berbasis problem solving Polya peserta didik dituntut untuk berpikir logis, sistematif, kreatif, dan mandiri sesuai dengan tahapan penyelesaian soal yang diberikan. Pada Gambar 2 dapat dilihat rata-rata persentase hasil penilaian pembelajaran Fisika menggunakan LKPD berbasis problem solving Polya pada pertemuan pertama sebesar $77,33 \%$ dengan kategori baik.

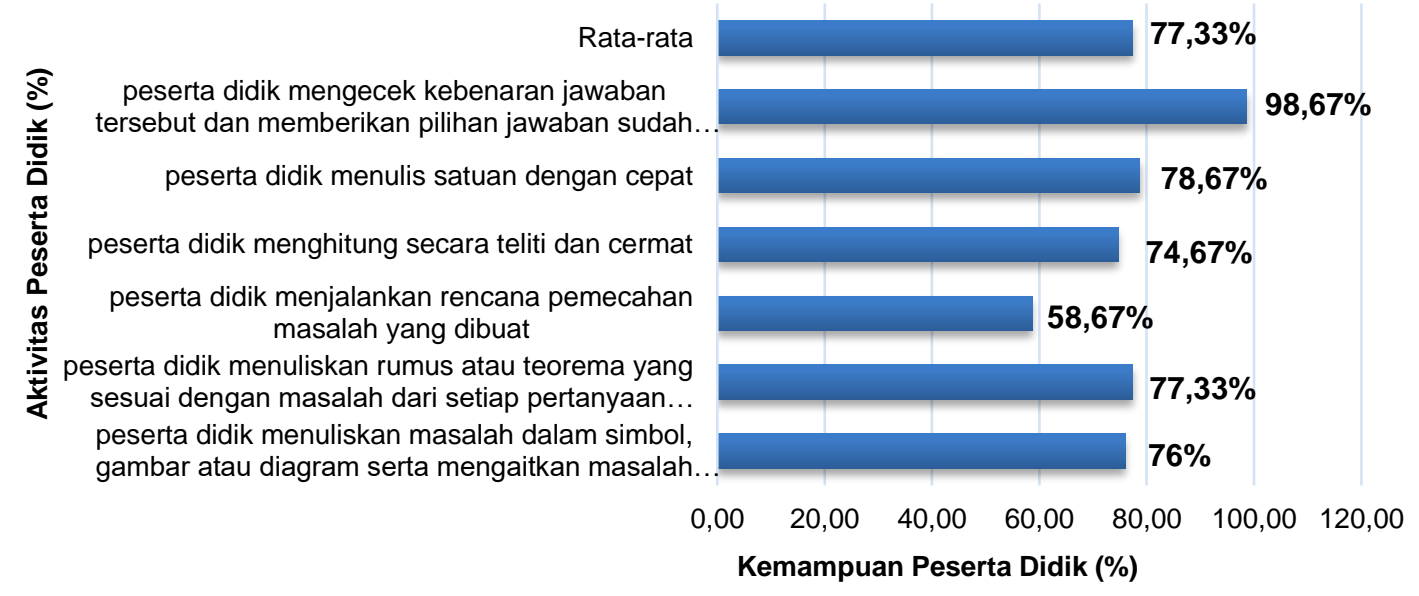

Gambar 2. Rata-rata persentase hasil penilaian pembelajaran fisika pertemuan pertama

Pada Gambar 3 dapat dilihat ratarata persentase hasil penilaian pembelajaran fisika menggunakan
LKPD berbasis problem solving Polya pada pertemuan pertama sebesar $81,11 \%$ dengan kategori sangat baik. 


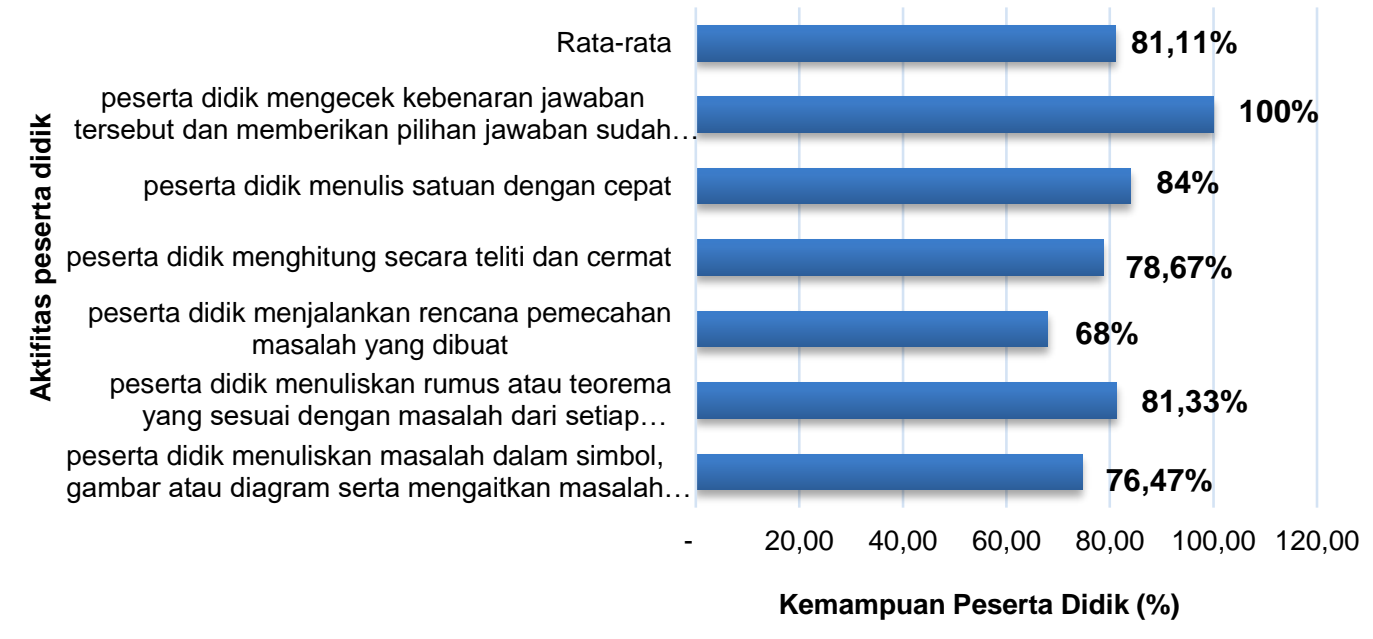

Gambar 3. Rata-Rata Persentase Hasil Pembelajaran Fisika Pertemuan Kedua

Pada Gambar 4 dapat dilihat ratarata persentase hasil penilaian pembelajaran Fisika menggunakan LKPD berbasis problem solving Polya pada pertemuan pertama sebesar $78,89 \%$ dengan kategori baik. Pada hasil pertemuan ketiga terdapat sedikit penurunan rata-rata persentase hasil penilaian hal ini dikarenakan oleh peneliti mengubah kategori soal dengan meningkatkan

\begin{abstract}
menganalisis dalam memecahkan permasalahan dari soal yang diberikan dibandingkan pertemuan pertama dan pertemuan kedua. Peserta didik yang masih terpaku pada kategori soal pada pertemuan sebelumnya sehingga kesulitan menyelesaikan soal yang dibuat berbeda tetapi hasil pembelajaran masih masuk dalam kategori baik.
\end{abstract}

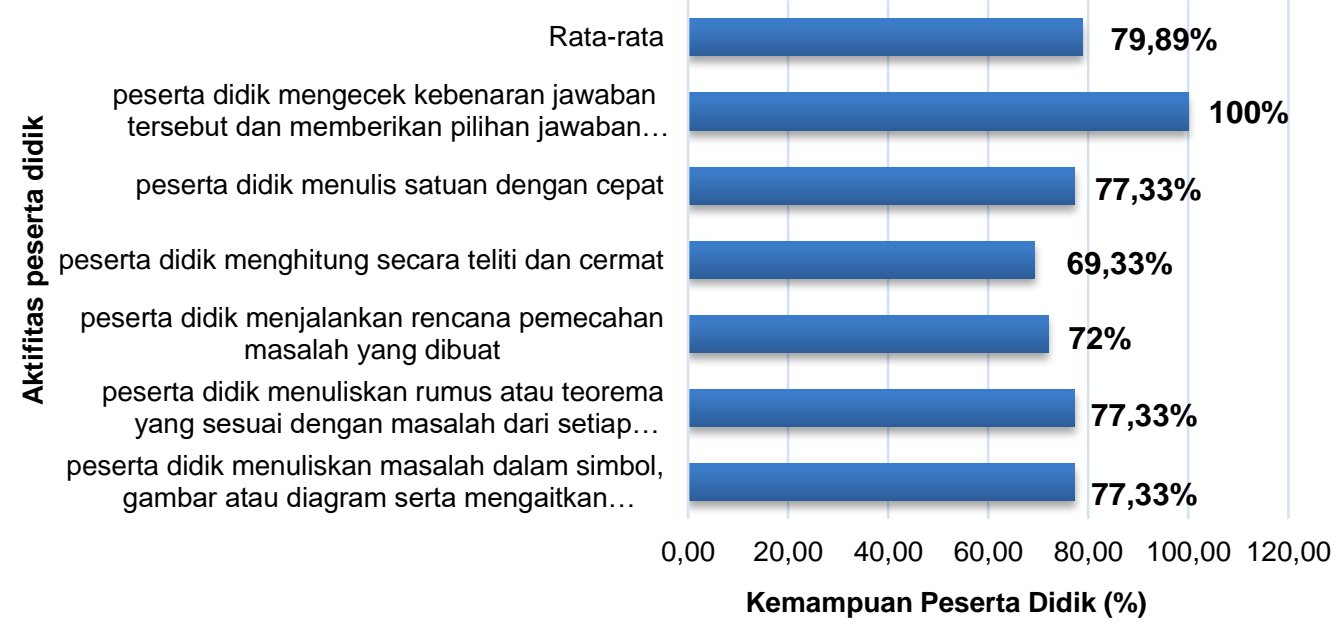

Gambar 4. Rata-Rata Persentase Hasil Penilaian Pembelajaran Fisika Pertemuan Ketiga

Dengan menggunakan LKPD berbasis problem solving Polya dituntut untuk semaksimal mungkin mungkin mencari tahu sendiri tanpa harus selalu menunggu jawaban dari guru atau teman yang lebih pintar saja. Peserta didik diajak untuk berpikir kritis, melakukan percobaan untuk menguji hipotesis mereka tentang suatu ilmu, bertanya jika ada yang mengerti, berani 
memberikan pendapat atau jawaban tanpa ada rasa takut salah, peserta didik dilatih bersosialisasi, menghargai perbedaan, dan bertanggung jawab dalam kelompok masing-masing karena semua aktifitas ini dilakukan dalam suasana yang menyenangkan (Anugrah, 2013). Implikasi

pembelajaran menggunakan LKPD berbasis problem solving Polya dapat meningkatkan kemampuan menganalisis peserta didik. Tampilan, desain, dan isi yg terdapat dalam LKPD berbasis problem solving Polya dapat meningkatkan kemampuan menganalisis peserta didik ketika dikombinasikan dengan metode pembelajaran yang sesuai dengan perkembangan peserta didik. Hal ini sesuai dengan teori problem soving menurut Polya (1947) yaitu model problem soving Polyadapat digunakan untuk membantu peserta didik dalam meningkatkan menganalisis.

\section{SIMPULAN DAN SARAN}

Berdasarkan penelitian yang telah dilakukan dapat disimpulkan bahwa validitas perangkat pembelajaran fisika berupa LKPD berbasis problem solving Polya pada materi kalor yang divalidasi oleh dua validator dinyatakan valid dan reliabel. Hal ini dilihat dari hasil analisis valiasi antara 0-1 dan uji reliabilitas ditunjukkan dengan nilai $r_{\text {hitung }}>r_{\text {tabel. }}$ Analisis angket respon peserta didik terhadap LKPD berbasis problem solving Polya pada materi kalor dinyatakan praktis. Dapat dilihat dari hasil rata-rata persentase angket respon peserta didik sebesar 93\% dengan kategori sangat baik. Analisis lembar penilaian pembelajaran Fisika dengan menggunakan LKPD berbasis problem solving Polya dinyatakan efektif. Dapat dilihat dari rata-rata persentase hasil penilaian pada pertemuan pertama sebesar $77,33 \%$ dengan kategori baik. Pada pertemuan kedua didapat ratarata persentase hasil penilaian sebesar $81,11 \%$ dengan kategori sangat baik dan rata-rata persentase hasil penilaian pada pertemuan ketiga sebesar 78,89 dengan kategori baik.
Adapun saran berdasarkan penelitian yang telah dilakukan adalah: Penelitian LKPD berbasis problem solving Polya ini merupakan penelitian yang berlanjut. Sesuai dengan tujuan untuk meningkatkan kemampuan menganalisis peserta didik sehingga untuk penelitian selanjutnya diharapkan dapat mengembangkan LKPD berbasis problem solving Polya dengan meningkatkan analisis soal. Sehingga kemampuan menganalisis peserta didik juga meningkat. Pengembangan perangkat pembelajaran berupa LKPD berbasis problem solving Polya ini diharapkan dapat digunakan untuk SMP Kelas VII, sehingga tidak hanya diuji penilaian pembelajaran dan respons pada satu sekolah saja tetapi di beberapa sekolah lainnya.

\section{DAFTAR PUSTAKA}

Anderson, O. W., \& Krathwohl, D. R. (2010). "Kerangka Landasan untuk Pembelajaran Pengajaran Dan Assesmen Revisi Taksonomi Pendidikan Bloom", Terjemahan. Jakarta: Pustaka Belajar.

Arikunto, S. (2006). Prosedur Penelitian Suatu Pendekatan Praktik. Rineka Cipta. Jakarta: Rineka Cipta. Retrieved from http://search.ebscohost.com/login. aspx?direct=true $\& \mathrm{db}=\mathrm{a} 9 \mathrm{~h} \& \mathrm{AN}=10$ 2221640\&site $=$ ehost-live

Asmawati, E. Y. (2015). Lembar Kerja Siswa (LKS) Menggunakan Model Guided Inquiry Untuk Meningkatkan Keterampilan Berpikir Kritis Dan Penguasaan Konsep Siswa. Jurnal Pendidikan Fisika, 3(1), 15. https://doi.org/10.24127/jpf.v3i1.13

Aziz Aisyah, Y. I. (2013). Aktivitas dan Persepsi Peserta Didik dalam Implementasi Multimedia Virtual pada Materi Fisika Modern di SMP. Jurnal Berkala Fisika Indonesia, 5(2), 38.

Depdiknas. (2006a). Permendiknas Nomor 22 tentang Standar Isi.

Depdiknas. (2006b). Standar Isi untuk 
Satuan Pendidikan Dasar dan Menengah. BSNP. Jakarta.

Hayati, M. N., Supardi, K. I., \& Miswadi, S. S. (2013). Pengembangan pembelajaran ipa smk dengan model kontekstual berbasis proyek untuk meningkatkan hasil belajar dan keterampilan proses sains siswa. Jurnal Pendidikan IPA Indonesia, 2(1), 53-58. https://doi.org/10.15294/jpii.v2i1.25 10

Hidayat, T. (2014). Pengaruh Penggunaan LKS Berbasis Problem Solving Polya Materi Fluida Dinamis terhadap Kemampuan Menganalisis Peserta didik. Universitas Islam Negeri Syarif Hidayatullah.

Ikhwanuddin, Jaedund, A., \& Purwantoro, D. (2010). Problem Solving Dalam Pembelajaran Fisika Untuk Meningkatakan Kemampuan Mahasiswa Berpikir Analitis. Jurnal Kependidikan, 40(2), 215-230.

Isnaningsih, A., \& Bimo, D. S. (2013). Penerapan lembar kegiatan siswa (LKS) discovery berorientasi keterampilan proses sains untuk meningkatkan hasil belajar IPA. Jurnal Pendidikan IPA Indonesia, 2(2), 138. https://doi.org/10.15294/jpii.v2i2.27 14

Jamhari. (2010). Penerapan Pendekatan Problem Solving dalam Meningkatkan Kemampuan Berfikir Kritis Peserta didik SMP Negeri 21 Palu pada Mata Pelajaran Biologi. Jurnal Biodidaktis, 3(2), 84.

Kokom, K. (2011). Penerapan Metode Pembelajaran Problem Solving Model Polya Untuk Meningkatkan Kemampuan Memecahkan Masalah Bagi Siswa Kelas IX J Di SMPN 3 Cimahi. In Prosiding seminar nasional penelitian, pendidikan dan penerapan MIPA Fakultas MIPA UNY (p. 1).

Lawshe, C. H. (1975). A Quantitative
Approach to Content Validity. Chicago: Personnel Psychology.

Nasir Muhammad, A. H. dan N. S. (2014). Pengembangan LKS Inkuiri Terintegrasi Generik Sains pada Materi Fluida Statis. N Jurnal IImu Pendidikan, 21(2), 192.

Nessa, A. (2013). Pengaruh LKPD Berbasis Pq4R terhadap Hasil Belajara IPA Fisika Kelas VII SMP $\mathrm{N} 1$ Linggo Sari Baganti. In Pillar Of Physic Education.

Permendiknas nomor 23 tahun 2007 tentang Standar Kompetensi Lulusan. (n.d.).

Polya, G. (1947). "How To Solve 1,2nd Ed". New Jersey: Pricenton University Press.

Poppy., K. (n.d.). Pengembangan Perangkat Pembelajaran. Bandung: PTK IPA. https://doi.org/p-ISSN:2089-5003

Prastowo, A. (2013). Panduan Kreatif Membuat Bahan Ajar Inovatif. Jogjakarta: Diva Press.

Risdiyani, S. dan. (2013). PR Fisika. Klaten: Intan Pariwara.

Sidharta, A. (2007). Keterampilan Berpikir Kompleks dan Implementasinya dalam Pembelajaran IPA. Depdiknas. Bandung: Depdiknas.

Sudjana, N. (2008). Penilaian Proses Hasil Belajar Mengajar. Bandung: Remaja Rosda Karya.

Thiagarajan, Sivasailam, E. A. (1974). Instructional development for training teachers of exceptional children. Yogyakarta: Kanisius.

Trianto. (2007). Model Pembelajaran Terpadu dalam Teori dan Praktek. Jakarta: Prestasi Pustaka.

Trianto. (2011). Mendesain Model Pembelajaran Inovatif - Progresif. Jakarta: Jakarta Kencana.

Undang - Undang Republik Indonesia No. 20 Tahun 2003 Tentang Sistem Pendidikan Nasional. (2003). Retrieved from 
http://setneg.go.id/index.php?optio $\mathrm{n}=$ com_perundangan\&id=323\&tas $\mathrm{k}=$ detail\&catid $=1$ \&ltemid $=42 \&$ tahu $\mathrm{n}=2003$

Widiana, I. W., \& Jampel, N. (2016). Learning Model and Form of Assesment toward The Inferensial Statistical Achievement by Controlling Numeric Thingking Skills Achievement Form of assessment Inferential statistical Learning model Numeric thinking skills. International Journal of Evaluation and Research in Education (IJERE). Retrieved from http://iaesjournal.com/online/index. php/IJERE

Widyaningsih, S.W., \& Yusuf, I. (2015). Penerapan Pembelajaran Listrik Dinamis Model Kooperatif Tipe STAD Menggunakan Pendekatan CTL dengan Integrasi Nilai. Jurnal Pancaran, 4(2), 223-234.

Widyaningsih, S. W. (2011). Pembentukan Karakter Bertanggung Jawab dan Rasa Ingin Tahu Melalui Penerapan Metode Quantum Learning dengan Menggunakan Media Alat Peraga Sederhana pada Pembelajaran Fisika. In Prosiding Seminar Nasional MIPA dan Pendidikan MIPA. Padang: Universitas Negeri Padang. 